\title{
Study on Yield Variability in Oil Palm Progenies and Their Genetic Origins ${ }^{\dagger}$
}

\author{
Senesie Swaray ${ }^{1,2, *} \mathbb{0}$, Mohd Y. Rafii ${ }^{1,3, * \mathbb{C}}$, Mohd Din Amiruddin ${ }^{4}$, Mohd Firdaus Ismail ${ }^{1}$, Syari Jamian ${ }^{5}$, \\ Marhalil Marjuni ${ }^{4}$, Momodu Jalloh ${ }^{1,2}{ }^{(\mathbb{D}}$, Oladosu Yusuff ${ }^{3}\left(\mathbb{D}\right.$ and Mohd Mustakim Mohamad ${ }^{4}(\mathbb{D}$
}

1 Department of Crop Science, Faculty of Agriculture, Universiti Putra Malaysia (UPM), Serdang 43400, Selangor, Malaysia; mohd.firdaus@upm.edu.my (M.F.I.); jalcoke2008@gmail.com (M.J.)

2 Tree Crop Unit, Sierra Leone Agricultural Research Institute (SLARI), Freetown P.M.B. 1313, Sierra Leone

3 Laboratory of Climate-Smart Food Crop Production, Institute of Tropical Agriculture and Food Security, Universiti Putra Malaysia (UPM), Serdang 43400, Selangor, Malaysia; oladosuy@gmail.com

4 Advanced Biotechnology and Breeding Centre, Malaysian Palm Oil Board, 6 Persiaran Institusi, Bandar Baru Bangi, Kajang 43000, Selangor, Malaysia; mohddin@mpob.gov.my (M.D.A.); marhalil@mpob.gov.my (M.M.); mohd.mustakim@mpob.gov.my (M.M.M.)

5 Department of Plant Protection, Faculty of Agriculture, Universiti Putra Malaysia (UPM), Serdang 43400, Selangor, Malaysia; syari@upm.edu.my

* Correspondence: senesieswaray74@gmail.com (S.S.); mrafii@upm.edu.my (M.Y.R.)

+ Presented at the 1st International Electronic Conference on Plant Science, 1-15 December 2020; Available online: https:/ /iecps2020.sciforum.net/.

Citation: Swaray, S.; Rafii, M.Y.; Amiruddin, M.D.; Ismail, M.F.; Jamian, S.; Marjuni, M.; Jalloh, M.; Yusuff, O.; Mohamad, M.M. Study on Yield Variability in Oil Palm Progenies and Their Genetic Origins. Biol. Life Sci. Forum 2021, 4, 68. https: / / doi.org/10.3390/ IECPS2020-08760

Academic Editor: Yoselin Benitez-Alfonso

Published: 1 December 2020

Publisher's Note: MDPI stays neutral with regard to jurisdictional claims in published maps and institutional affiliations.

Copyright: (c) 2020 by the authors. Licensee MDPI, Basel, Switzerland. This article is an open access article distributed under the terms and conditions of the Creative Commons Attribution (CC BY) license (https:// creativecommons.org/licenses/by/ $4.0 /)$.

\begin{abstract}
One of the most important and widely known plantation crops with high revenue returns is the Elaeis guineensis palm. To date, yield variability in fresh fruit bunches (YFFB) in Malaysian oil palm plantations is one of the key influences in low palm oil yield. Accordingly, an assessment of dura $\times$ pisifera progenies and their genetic origins on oil palm yield was investigated. Twenty-four derived progenies from 10 genetic sources were adopted as F1 hybrid-single generation and the standard approach for data collection of the yield and yield traits was followed for three sequential years. Variance analysis showed genetic differences between the progenies and their origins. Amid the progenies analyzed, $45.83 \%$ had YFFB above the trial mean. Progeny HPDP500 had the highest YFFB (191.74 kg/palm/year) and the highest bunch number (YBNO) was recorded in PKDP4474 (20.65 bunches/palm/year), and HPDP500 (20.53 bunches/palm/year). In year one and year three, the highest YFFB was reported, while in year one of data collection, the highest YBNO was recorded. Dura-Ulu Remis $\times$ Yangambi had the highest YFFB $(175.81 \mathrm{~kg} /$ palm/year) and Tanzania $\times$ Nigeria recorded the highest YBNO (19.06 bunches/palm/year). High heritability and phenotypic coefficient of variation with a moderate genotypic coefficient of variation for all the traits were further revealed. YFFB had a moderate positive YBNO relationship ( $\mathrm{r}=0.676 ; \mathrm{df}=3,23 ; p=0.0001)$ and a weak positive average bunch weight correlation $(\mathrm{r}=0.378 ; \mathrm{df}=3,23 ; p=0.0001)$. For tissue culture and hybridization programs for yield enhancement, progenies and origins with better performance may be used; however, the use of molecular research as a selection criterion seems to be worth further analysis.
\end{abstract}

Keywords: genetic origins; yield traits; genetic variance; progeny; heritability

\section{Introduction}

The African oil palm (Elaeis guineensis Jacq) is a native of Sierra Leone, mostly found in coastal areas, which may have spread to other parts of West Africa countries, such as Liberia, Guinea, Guinea Bissau, Ivory Coast, Nigeria, Angola, Tanzania, and Cameroon. However, Maluin et al. [1] reported that the palm species guineensis originated from the tropical rainforest in West Africa The presence of substantial genetic diversity in Nigerian oil palm populations suggests that it could be the center of origin of the palm species 
guineensis Jacq and to improve yield performances by increasing the heterosis effect, and decreasing inbreeding depression, future oil palm breeding programs should prioritize estimating the magnitude of the genetic distance across accessions [2]. Oil palm is an extremely gainful source of revenue from exports in tropical areas [3]. Oil palm is the most oil-producing oleaginous crop, producing four to six tons of palm oil per hectare on average [4]. Per unit area of land, its yield is five times higher than all other oilseed crops [5]. Oil palm is a source of food for an ever-growing population of humans and animals, its products are used as raw materials for industries, biofuel, and above all, and it has created countless well-paying jobs for millions of people across the world. In several traditional recipes, one of the compulsory ingredients is locally produced crude palm oil (CPO) [6]. According to Rebena et al. [7] 80\% CPO accounts for approximately $1 / 3$ of the entirety of edible oil consumption. This is due to its valuable nutritional properties [8].

The use of dura $\times$ pisifera progeny planting materials has led to significant yield improvement in oil palm [9]. However, the continuous variability of fresh fruit bunch (YFFB) yield is highly pronounced in Malaysia oil palm plantations. The YFFB yield in Malaysia for four consecutive years has clearly shown variability in yield as reported by MPOB [10] and Kushairi et al. [11], thus: (2015 (18.48 t/ha), 2016 (15.91 t/ha), 2017(19.92 t/ha) and $2018(17.16 \mathrm{t} / \mathrm{ha}))$. African countries, for example, could yield two metric tons (Mt) of palm oil per year, export one Mt/yr and import about eight Mt/yr [12]. Since the 1990s, the palm oil sector in Africa has been thriving despite the low land output of oil ( $\mathrm{t}$ oil/ha) and it is presently intensifying $[13,14]$. However, non-selected and unproductive planting material in the sector has been one of the limiting factors [6,15], as well as inadequate agricultural management practices [16], yield losses and low oil extraction rates (OEC) especially among small-scale farmers [17].

In Malaysia, oil palm is considered as an important commodity crop with revenue return in 2018, reaching higher than Ringgit Malaysia (RMY) 67.12 billion and in 2019, a $4.0 \%$ visible decline was observed when compared to the RMY 67.12 billion export revenue in 2018 [18]. A decline in oil yield (OY) palm/ha has been associated with variability in the YFFB yield, which has ultimately resulted in serious economic losses in the oil palm industry, especially for small-scale farmers. Sarkar et al. [19] reported that the higher negative effects on agricultural production than positive impact are due to climate change. Climate change in Malaysia has a significant influence on the variability of oil palm yield; accordingly, the Malaysian oil palm sector's sustainability is ultimately affected [19]. A previous investigation carried out by Kushairi et al. [11] reported that the year 2018 was known to be the most challenging period for the oil palm industry in Malaysia, with a lower yield of $19.52 \mathrm{t} / \mathrm{ha}$, comprising palm oil prices and exports. The decline in palm oil prices coupled with its weak demand caused a decline in export earnings in 2018 to RMY 65.12 billion, compared to 2017 earnings of RMY 74.75 billion [11]. Low oil yield will bring about economic instability among oil palm growers and the nation at large. Oil palm remains the power house for Malaysia's economy even though there is a decline in oil palm fruit set resulting to low YFFB.

According to Kushairi et al. [11], in the year 2018, a 4.1\% reduction in oil palm fresh fruit bunches was noticed when compared to the fresh fruit bunch output of 2017: specifically, $17.89 \mathrm{t} /$ hain 2017 in comparison to $17.16 \mathrm{t} /$ hain 2018. In different parts of oil palm cultivated countries in which Malaysia is no exception, numerous efforts have been made to identify and to address the causes of low YFFB yield in oil palm plantations, of which palm planting materials are no exception. Thus, this research is intended to assess dura $\times$ pisifera (DP) progenies and their genetic origins' effects on oil palm fresh fruit bunch (YFFB) yield.

\section{Hypothesis of the Study}

The following hypothesis will be investigated:

1. $\mathbf{H}_{\mathbf{0}}$. There is no significant variation in YFFB yield performance among the progenies.

$\mathbf{H}_{\mathbf{1}}$. The performance of the progenies in YFFB yield varies significantly. 
2. $\mathbf{H}_{\mathbf{0}}$. There is no significant variation in their performance for YFFB yield.

$\mathbf{H}_{\mathbf{1}}$. There is significant variation in genetic origins' performance for $Y F F B$ yield.

3. $\mathbf{H}_{\mathbf{0}}$. The genetic variance cannot influence low YFFB yield in oil palm progenies.

$\mathbf{H}_{\mathbf{1}}$. The genetic variance could influence low YFFB yield in oil palm progenies.

4. $\quad \mathbf{H}_{\mathbf{0}}$. There is no significant variation in yearly performance for $Y F F B$.

$\mathbf{H}_{\mathbf{1}}$. There is significant variation in yearly performance for $Y F F B$.

\section{Materials and Method}

A total of 24 DP progenies (HPDP415, HPDP500, HPDP550, HPDP618, PKDP4118, PKDP4465, PKDP4474, PKDP4482, PKDP4504, PKDP4505, PKDP4529, PKDP4535, PKDP4539, PKDP4540, PKDP4548, PKDP4550, PKDP4570, PKDP4591, PKDP4621, PKDP4648, PKDP4651, PKDP4674, PKDP4679 and PKDP4841 derived from 10 parental origins ((six female Duras: Deli-Serdang, Deli-Ulu Remis, Deli-Banting, Deli-Johor Labis, Tanzania, and Angola) and four male pisiferas: Yangambi, AVROS, Cameroon and Nigeria)) were planted in 2008 at MPOB Teluk-Intan Research Station, Malaysia at Trial 0.52 at the coordinate of $3^{\circ} 49^{\prime} 3.1100^{\prime \prime}$ $\mathrm{N}$ and $101^{\circ} 3^{\prime} 8.9100^{\prime \prime} \mathrm{E}$. These progenies were planted in an independent completely randomized design (ICRD) in four replications with sixteen palms per family, per replicate and $8.5 \mathrm{~m} \times 8.5 \mathrm{~m} \times 8.5 \mathrm{~m}$ planting distance was used. In eleven-year-old experimental palms laid-down on a peat-soil, 480 palms were selected from a total palm density of 1930 palms (12.06 hectares) and were monitored for yield and yield components for three consecutive years (2017-2019) initiated by MPOB.

\subsection{Data Collection}

Three years of data recording were conducted on individually selected progeny palms for the fresh fruit bunch (YFFB), bunch number (YBNO), and average bunch weight (YABW). The data collection of these selected component traits was carried out at fortnightly intervals (after every two weeks) or two rounds monthly, following the standard procedures of Rafii et al. [20,21] and Shabanimofrad et al. [22]. This study followed all applicable institutional, international and national norms and regulations.

\subsection{Statistical Analysis}

The calculated mean data by progenies were subjected to version 9.4 of the Statistical Analysis System (SAS) for the analysis of variance employing the general linear model (PROC GLM) due to some missing and uneven distribution of progeny's palms. Descriptive statistics such as mean, coefficient of variation (CV), and standard error (SE) were determined. For mean comparison at a 5\% probability level, Duncan's new multiple range tests (DNMRT) were used. SAS (version 9.4) was used for Proc varcomp using restricted maximum likelihood (REML) for variance components estimation and the correlation coefficient was estimated. The genotypic and phenotypic coefficients of variation and heritability were calculated following the procedures and formulae of Burton [23,24], Singh and Chudhary [25], and Johnson et al. [26].

(a) Heritability estimate $\left(h_{B}^{2}\right)$ :

$$
h_{B}^{2}=\frac{\sigma_{g}^{2}}{\sigma_{p}^{2}} \times 100
$$

where, $h_{B}^{2}=$ Heritability of broad sense, $\sigma_{p}^{2}=$ Phenotypic variance, $\sigma_{g}^{2}=$ Genotypic variance.

Heritability was estimated as categorized by Robinson et al. [27] followed by Johnson et al. [26] as high $(>60 \%)$, moderate $(30-60 \%)$, and low $(<30 \%)$.

(b) Phenotypic coefficients of variation (PCV):

$$
P C V=\frac{\sqrt{\sigma_{P}^{2}}}{\bar{X}} \times 100
$$

where, $\bar{X}=$ Progeny population mean, $\sigma_{P}^{2}=$ Phenotypic variance. 
(c) Genotypic coefficients of variation (GCV):

$$
G C V=\frac{\sqrt{\sigma_{g}^{2}}}{\bar{X}} \times 100
$$

where, $\sigma_{g}^{2}=$ Genotypic variance, $\bar{X}=$ Progeny population mean.

The genotypic and phenotypic coefficients of variation value estimates were categorized as high $(>20 \%)$, moderate $(10-20 \%)$, and low (0 to $10 \%)$ according to Oladosu et al. [28].

\section{Results and Discussion}

\subsection{Experimental Findings on Yield Traits in DP Progenies}

Analysis of variance (ANOVA) for yield traits of 24 single crossed dura $\times$ pisifera (DP) progenies presented highly significant differences $(p \leq 0.01)$ (Table 1$)$. This result was in agreement with the findings of Arolu et al. [29]; they reported in their early studies that the ANOVA of biparental progenies was highly significant for yield and yield traits. This certainly indicated the magnitude of genetic disparity that exists among DP progenies and in terms of selection and breeding programs, they can be exploited for yield improvement. The analysis also showed significant differences $(p \leq 0.01)$ among the years for yield traits, inferring inconsistencies in the yield traits' performance across the years. However, the interaction between yearly and progeny showed significant differences $(p \leq 0.05)$ for YFFB and YBNO, while no significant difference was noticed for YABW. However, due to the homogeneity of the replications, no significant differences were manifested among them.

Table 1. Mean square and estimates of variance components for yield traits among progenies.

\begin{tabular}{|c|c|c|c|c|}
\hline Source of Variation & DF & YFFB (kg/Palm/Year) & YBON (Bunch/Palm/Year) & YABW (kg/Palm/Year) \\
\hline Replications (R) & 3 & $318.74^{\mathrm{ns}}$ & $1.28^{\mathrm{ns}}$ & $1.06^{\mathrm{ns}}$ \\
\hline Years $(\mathrm{Y})$ & 2 & $1973.68^{* *}$ & $775.92 * *$ & $142.38^{* *}$ \\
\hline Progenies (G) & 23 & $7102.22 * *$ & $88.14^{* *}$ & $23.99 * *$ \\
\hline $\mathrm{Y} * \mathrm{G}$ & 46 & $507.90 *$ & 5.23 * & $1.57^{\mathrm{ns}}$ \\
\hline Error & 186 & 557.42 & 3.60 & 1.23 \\
\hline \multicolumn{5}{|c|}{ Variance component } \\
\hline \multicolumn{2}{|c|}{$\sigma^{2} g$} & $\begin{array}{l}645.85 \\
(61.83)\end{array}$ & $\begin{array}{c}7.60 \\
(65.37)\end{array}$ & $\begin{array}{c}2.21 \\
(62.60)\end{array}$ \\
\hline \multicolumn{2}{|c|}{$\sigma^{2} y g$} & $\begin{array}{l}41.43 \\
(3.97)\end{array}$ & $\begin{array}{c}0.45 \\
(3.87)\end{array}$ & $\begin{array}{c}0.10 \\
(2.83)\end{array}$ \\
\hline \multicolumn{2}{|c|}{$\sigma^{2} \mathrm{e}$} & $\begin{array}{l}357.22 \\
(34.20)\end{array}$ & $\begin{array}{c}3.58 \\
(30.76)\end{array}$ & $\begin{array}{c}1.22 \\
(34.58)\end{array}$ \\
\hline \multicolumn{2}{|c|}{ Mean } & 145.41 & 15.41 & 9.34 \\
\hline \multicolumn{2}{|c|}{ SE } & 2.08 & 2.26 & 0.12 \\
\hline \multicolumn{2}{|c|}{$\mathrm{CV}$} & 23.16 & 27.16 & 22.50 \\
\hline
\end{tabular}

Note: $\mathrm{DF}=$ degree of freedom, YFFB = fresh fruit bunch, $\mathrm{YBNO}=$ number of bunches, YABW = average bunch weight, $\sigma_{g}^{2}=$ genotypic variance, $\sigma_{y g}^{2}=$ year $\times$ genotypic variance, $\sigma_{e}^{2}=$ error variance, ${ }^{* *}=$ highly significant at $p \leq 0.01,{ }^{*}=$ significant $p \leq 0.05$, ns $=$ non-significant $p>0.05$. The phenotypic variances in percentage are the values in brackets. $\mathrm{SE}=$ standard error, $\mathrm{CV}=$ coefficient of variation.

Table 1 presents the variance components results obtained in the current study, which showed that superior genetic variability existed among the DP progenies. It was observed that genetic variance $\left(\sigma_{\mathrm{g}}^{2}\right)$, which varied from $61.83 \%$ to $65.37 \%$, was found to be higher across the traits analyzed, indicating that variation in DP progeny traits could be attributed to genetic effect which could have influenced the YFFB yield, whereas error variance $\left(\sigma_{e}^{2}\right)$ was noticed to be low across all the traits, implying that the environmental effect on progeny traits was low.

The mean differences in yearly and DP progenies' performance for yield component traits (YFFB, YBNO, and YABW) are presented in Table 2 . The best yearly performance 
for YFFB was observed in year three and year one, with nonsignificant difference between them, and the lowest YFFB was obtained in year two. Moreover, the lowest YBNO and YABW were noticed in year two and year one, respectively. This shows that the variability in the years' performance could be influenced by differences in climatic factors. The results were in agreement with the findings of Oettli et al. [30]; they reported that for all regions in Malaysia, a strong variability in annual oil palm yields was observed, with noticeable rises and drops in yield during the 28 years study period [30]. The dry spell is expected to diminish crude palm oil production, and most cropping schemes are rainfed [31] of which oil palm is no exception.

Table 2. Yearly and progeny means for yield and yield traits of biparental progenies.

\begin{tabular}{|c|c|c|c|}
\hline YEAR & YFFB (kg/Palm/Year) & YBON (Bunch/Palm/Year) & YABW (kg/Bunch) \\
\hline YEAR1 (2017) & $153.69 a$ & $18.89 a$ & $8.00 \mathrm{c}$ \\
\hline YEAR2 (2018) & $128.14 b$ & $13.35 \mathrm{c}$ & $9.45 b$ \\
\hline YEAR3 (2019) & $154.40 \mathrm{a}$ & $14.00 \mathrm{~b}$ & $10.58 \mathrm{a}$ \\
\hline \multicolumn{4}{|l|}{ Progeny } \\
\hline HPDP415 & $129.55 i$ & $11.78 \mathrm{ij}$ & $11.19 \mathrm{ab}$ \\
\hline HPDP500 & $191.74 a$ & $20.52 a$ & 9.48efg \\
\hline HPDP550 & 136.35hi & $11.73 \mathrm{ij}$ & $11.47 a^{\circ}$ \\
\hline HPDP618 & 142.22fghi & $14.50 \mathrm{efg}$ & 9.62defg \\
\hline PKDP4118 & $136.75 \mathrm{hi}$ & 14.12fhg & $9.85 \mathrm{def}$ \\
\hline PKDP4465 & 138.22hi & $15.60 \mathrm{ef}$ & $9.09 \mathrm{fgh}$ \\
\hline PKDP4474 & 144.25fghi & $20.65 a$ & $6.71 \mathrm{jk}$ \\
\hline PKDP4482 & $89.78 \mathrm{k}$ & 12.37hij & $6.07 \mathrm{k}$ \\
\hline PKDP4504 & 154.69defgh & $15.25 \mathrm{ef}$ & $9.32 \mathrm{fg}$ \\
\hline PKDP4505 & $171.80 \mathrm{bcd}$ & $17.64 \mathrm{~cd}$ & 10.23 bcdef \\
\hline PKDP4529 & $176.42 \mathrm{abc}$ & 16.30de & $11.03 \mathrm{abc}$ \\
\hline PKDP4535 & $108.44 \mathrm{j}$ & $11.84 \mathrm{ij}$ & $8.62 \mathrm{gh}$ \\
\hline PKDP4539 & 152.02efgh & $17.69 \mathrm{~cd}$ & $8.22 \mathrm{hi}$ \\
\hline PKDP4540 & 168.31bcde & $18.57 \mathrm{bc}$ & 9.09fgh \\
\hline PKDP4548 & 175.01abc & $18.28 \mathrm{bc}$ & 9.63defg \\
\hline PKDP4550 & 158.99cdefg & $16.41 \mathrm{de}$ & 9.95cdef \\
\hline PKDP4570 & $110.86 \mathrm{j}$ & 14.09fgh & 7.61ij \\
\hline PKDP4591 & 180.07ab & $16.25 \mathrm{de}$ & $11.25 \mathrm{ab}$ \\
\hline PKDP4621 & 94.99jk & $10.86 \mathrm{j}$ & $6.99 \mathrm{jk}$ \\
\hline PKDP4648 & 141.25ghi & $14.58 \mathrm{efg}$ & 9.72defg \\
\hline PKDP4651 & 138.35hi & $19.78 \mathrm{ab}$ & $6.71 \mathrm{jk}$ \\
\hline PKDP4674 & 158.72cdefg & $15.24 \mathrm{ef}$ & 10.48abcde \\
\hline PKDP4679 & $160.48 \mathrm{cdef}$ & $14.20 \mathrm{fg}$ & 10.72abcd \\
\hline PKDP4841 & $129.91 \mathrm{i}$ & 12.90ghi & $10.09 \mathrm{cdef}$ \\
\hline Mean & 145.41 & 15.41 & 9.34 \\
\hline SE & 2.08 & 2.26 & 0.12 \\
\hline $\mathrm{CV}$ & 23.16 & 27.16 & 22.50 \\
\hline
\end{tabular}

Note: PKDP = Porim Kluang. dura $\times$ pisifera, HPDP $=$ Hulu Paka dura $\times$ pisifera, YFFB = fresh fruit bunch $\mathrm{YBNO}=$ number of bunches, YABW = average bunch weight, means with the same letters of alphabet within the same column are not significantly different at $p \leq 0.05$ based on Duncan's new multiple range test (DNMRT), $\mathrm{SE}=$ standard error, $\mathrm{CV}=$ coefficient of variation.

DNMRT revealed variations in the performance of the DP progenies (Table 2). The findings of this study were similar to the result obtained by Arolu et al. [29], who reported that due to differences in progenies, there was sufficient genetic variation for YFFB, YBNO and YABW, which gives ample scope for selection. The YFFB yield performance of the progenies ranged from 89.78 to $191.74(\mathrm{~kg} /$ palm/year) with a trial mean of 145.41 (kg/palm/year) and only $45.83 \%$ of the progenies had YFFB yield higher than the trial mean. It was observed that PKDP500 recorded the highest YFFB, followed by PKDP4591, and PKDP4482 had the lowest YFFB (Table 2). Similarly, the trial mean for YBNO was 15.41 (bunches/palm/year) and the progenies had a YBNO which varied from 
10.86 to 20.65 (bunches/palm/year) with $45.83 \%$ performing better than the trial mean value. It was observed that PKDP4621 recorded the least YBNO, while PKDP4474 and HPDP500, with no significant differences between them, had the highest YBNO, followed by PKDP4651. The progenies' trial mean for YABW was 9.34 (kg/bunch), with 58.33\% recorded the higher than the trial mean. However, the highest YABW was noticed in HPDP550. DNMRT indicated no significant difference between PKDP4591 and HPDP415 and they recorded the second-highest YBNO, whereas the lowest YABW was noticed in PKDP4482. The highest YFFB yield in HPDP500 occurred due to its highest YBNO with a moderate YABW. This result was in agreement with the findings of Myint et al. [32], who reported in their recent research findings that moderate YABW coupled with high YBON resulted in families with highest YFFB yields. In terms of the breeding and selection of oil palm, the emphasis has been on YFFB coupled with oil yield [33]. Therefore, as a result, HPDP500 performed the best for YFFB and it could be a good candidate for selection.

The analyzed morphological yield traits data showed that YFFB had a moderate positive significant correlation with $\mathrm{YBNO}(\mathrm{r}=0.67639 ; p=0.0001)$ and recorded a weak positive significant relationship with YABW at $\mathrm{r}=0.37840 ; p=0.0001$. On the contrary, YBNO exhibited a weak negative significant relationship with YABW at $\mathrm{r}=-0.34080$; $p=0.0001$. Genotypic and phenotypic levels of dissimilarity could be seen among the natural plant populations in cross-pollinated plants [34] of which oil palm is no exception. For rapid advancement in plant breeding, the basic tools for selection are estimates of the heritability, phenotype, and the genotypic coefficient of variations. A substantial quantity of variation must be seen in the selected component traits to reach ample possibility of reaching the response to selection [32,33,35]. In this study, broad-sense heritability (YFFB $61.83 \%$, YBNO 65.37\% and YABW 62.60\%) and PCV (YFFB 22.23\%, 22.12\%, and 20.13\%) were found to be high for all traits analyzed, indicating the influence of environmental effect, whereas for all the yield traits, GCV was found to be moderate at YFFB 17.48\%, YBNO 17.88\%, and YABW 15.93\%. The PCV was invariably higher than the corresponding GCV on the expression for each trait. Therefore, the influence of environmental factors that may contribute to a low YFFB yield could also be considered.

\subsection{Parental Origins' Performance in Oil Palm Yield and Yield Traits}

The yield trait performance among the genetic origins is presented in Figure 1. The origins' YFFB yield varied from 110.86 to 175.81 (kg/palm/year). Origin Tanzania $\times$ AVROS recorded the lowest YFFB yield and the highest YFFB was noticed in origin Deli-Ulu Remis $\times$ Yangambi. Similarly, Deli-Banting $\times$ AVROS had the least YBNO (11.76 bunches/palm/year) and Tanzania $\times$ Nigeria was observed with the highest YBNO at 19.06 bunches / palm/year.

Additionally, Tanzania $\times$ AVROS had the lowest YABW $(7.55 \mathrm{~kg} / \mathrm{bunch})$, whereas, Deli-Banting $\times$ AVROS had the maximum YABW $(11.33 \mathrm{~kg} / \mathrm{bunch})$. The low performance of Tanzania $\times$ AVROS for YFFB was due to its low YABW as a result of its moderate bunch size production. The size of the bunches produced determines the YABW, hence due to bigger bunches produced by Deli-Banting $\times$ AVROS recorded the highest YABW with the least YBNO produced. The outstanding performance of Deli-Ulu Remis $\times$ Yangambi in YFFB yield occurred because of the good combining characteristics of pisifera Yangambi. The pisifera Yangambi is characterized by early high yields, vigorous growth, thin-shell, ovoid fruit, and thin kernels [36], as a result, the poenttial benefits for oil palm development are increased. 


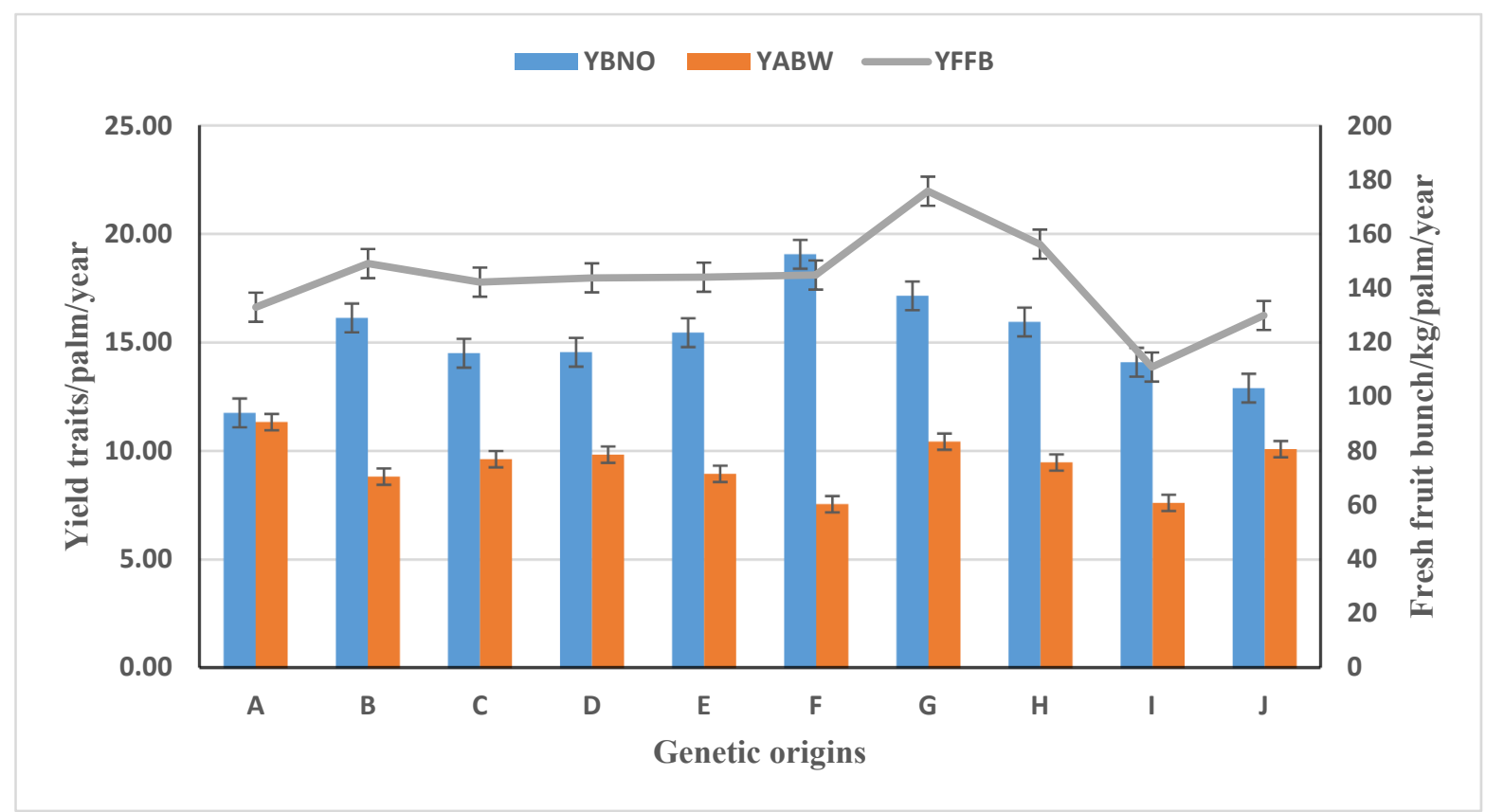

Figure 1. Genetic origins parental performance in yield and yield traits: (A) Deli-Banting $\times$ AVROS, (B) Deli-Ulu Remis $\times$ Nigeria, $(\mathbf{C})$ Deli-Johor Labis $\times$ AVROS, $(\mathbf{D})$ Deli Ulu Remis $\times$ AVROS, (E) Angola $\times$ AVROS, $(\mathbf{F})$ Tanzania $\times$ Nigeria, $(\mathbf{G})$ Deli-Ulu Remis $\times$ Yangambi, $(\mathbf{H})$ Angola $\times$ Nigeria, $(\mathbf{I})$ Tanzania $\times$ AVROS, $(\mathbf{J})$ Deli-Serdang $\times$ Cameroon

\section{Conclusions}

The fresh fruit bunch yield performance of the $24 \mathrm{DP}$ progenies with a range of 89.78 to $191.74 \mathrm{~kg} / \mathrm{palm} /$ year was reasonably good. A substantial variation for YFFB was observed among the progenies, with progeny HPDP500 as the highest and that with genetic origins of Deli-Ulu Remis $\times$ Yangambi as the most outstanding parent for YFFB. Due to the changeability in environmental factors, the annual performance for YFFB was also noticed to have influenced the YFFB yield and year three recorded the highest YFFB, with the least in year one. Moreover, the YFFB yield was influenced by the genetic effect as a result of the pedigree structure of the progenies used in this study. To further substantiate the YFFB yield, the correlation results show a positive significant relationship between YFFB and YBNO, indicating that an increase in YBNO will lead to an increase in YFFB. Heritability and PCV were found to be high in all the traits, while a moderate GCV was noticed in all the traits. However, progeny HPDP500 and origin Deli-Ulu Remis $\times$ Yangambi could be exploited for yield improvement in oil palm. High YFFB will bring about an increase in the economy, especially for small-scale farmers. The field quantitative research used in the identification of outstanding progenies and their origins in relation to YFFB demonstrated the potential in investigating and monitoring oil palm yield variability. Oil palm is typically adapted to low rainfall or dry climate, therefore, palms from these progenies may have the potential to resist heat stress and drought. Additionally, if combined with molecular research, such as the use of microsatellite molecular markers, the knowledge obtained from this study could have determine more of the core potential of progenies with maximum genetic variation and minimal accession, accordingly, decreasing the maintenance and expenditures in the oil palm sector. We propose future research combines conventional breeding with molecular studies.

Author Contributions: M.Y.R., M.D.A., M.F.I., S.J. and S.S. developed the concept; S.S. carried out the research; M.Y.R., M.D.A., M.F.I., S.J., M.M. and M.M.M supervised the experiment; M.Y.R., M.D.A., M.F.I., S.J., M.M., M.M.M., M.J., O.Y. and S.S. carried out software, formal analysis, and validation; S.S., M.J. and O.Y. carried out the calculations; S.S. drafted the manuscript; while the proofreading, editing, and finalizing were carried out by M.Y.R., M.D.A., M.F.I., S.J., O.Y. and M.J. All authors have read and agreed to the published version of the manuscript. 
Institutional Review Board Statement: Not applicable.

Informed Consent Statement: Not applicable for this study.

Data Availability Statement: The datasets that were used and analyzed in this investigation are available within this research article.

Acknowledgments: The authors wish to thank the Universiti Putra Malaysia (UPM) and the Malaysian Palm Oil Board (MPOB) for the knowledge and utilization of their research facilities, respectively. The first author also wish to thank the Sierra Leone Agricultural Research Institute (SLARI) for the support fellowship with Universiti Putra Malaysia for PhD studies.

Conflicts of Interest: The authors acknowledge no conflict of interest.

\section{References}

1. Maluin, F.N.; Hussein, M.Z.; Idris, A.S. An overview of the oil palm industry: Challenges and some emerging opportunities for nanotechnology development. Agronomy 2020, 10, 356. [CrossRef]

2. Bakoumé, C.; Wickneswari, R.; Siju, S.; Rajanaidu, N.; Kushairi, A.; Billotte, N. Genetic diversity of the world's largest oil palm (Elaeis guineensis Jacq.) field gene bank accessions using microsatellite markers. Genet. Resour. Crop Evol. 2015, 62, 349-360. [CrossRef]

3. Feintrenie, L.; Levang, P. Sumatra's rubber agroforests: Advent, rise and fall of a sustainable cropping system. Small-Scale For. 2009, 8, 323-335. [CrossRef]

4. Swaray, S.; Rafii, M.Y.; Din Amiruddin, M.; Firdaus Ismail, M.; Jamian, S.; Jalloh, M.; Oladosu, Y.; Mustakim Mohamad, M.; Marjuni, M.; Kolapo, O.K.; et al. Assessment of oil palm pollinating weevil (Elaeidobius kamerunicus) population density in biparental dura $\times$ pisifera hybrids on deep peat-soil in Perak state, Malaysia. Insects 2021, 12, 221. [CrossRef]

5. Hoffmann, M.P.; Vera, A.C.; Van Wijk, M.T.; Giller, K.E.; Oberthür, T.; Donough, C.; Whitbread, A.M. Simulating potential growth and yield of oil palm (Elaeis guineensis) with PALMSIM: Model description, evaluation and application. Agric. Syst. 2014, 131, 1-10. [CrossRef]

6. Nanda, D.; Kansci, G.; Rafflegeau, S.; Bourlieu, C.; Ebongue, G.N.; Genot, C. Impact of post-harvest storage and freezing of palm fruits on the extraction yield and quality of African crude palm oil extracted in the laboratory. OCL Oilseeds Fats Crops Lipids 2020, 27, 52. [CrossRef]

7. Rébéna, A.; Rafflegeau, S.; Kansci, G.; Nanda, D.; Genot, C. Surveys on the consumption, perception and uses of red palm oil among housewives and restaurateurs of Yaoundé, Cameroon. Cah. Agric. 2019, 28, 27. [CrossRef]

8. Dong, S.; Xia, H.; Wang, F.; Sun, G. The effect of red palm oil on vitamin A deficiency: A meta-analysis of randomized controlled trials. Nutrients 2017, 9, 1281. [CrossRef]

9. Ishak, Z.; Hashim, A.T.; Rosli, S.K.; Bakar, D.A.; Ooi, S.E.; Mohd, N.; Ong-Abdullah, M. Oil Palm Tissue Culture: Fast Tracking Elite Commercial Lines. In The Oil Palm Genome; Springer: Cham, Switzerland, 2020; pp. 47-68.

10. MPOB. Insect Pollination Efficiency in Oil Palm; Workshop; MPOB: Selangor, Malaysia, 2018.

11. Kushairi, A.; Ong-Abdullah, M.; Nambiappan, B.; Hishamuddin, E.; Bidin, M.N.I.Z.; Ghazali, R.; Subramaniam, V.; Sundram, S.; Parveez, G.K.A. Oil palm economic performance in Malaysia and R\&D progress in 2018. J. Oil Palm Res. 2019, 31, 165-194. [CrossRef]

12. Oil World. Independent Global Market Analyses E Forecasts Since 1958; ISTA Mielke Gmbh: Hamburg, Germany, 2018; Available online: https: / / www.oilworld.biz/t/publications / data-base (accessed on 15 June 2018).

13. Ordway, E.M.; Naylor, R.L.; Nkongho, R.N.; Lambin, E.F. Oil palm expansion in Cameroon: Insights into sustainability opportunities and challenges in Africa. Glob. Environ. Chang. 2017, 47, 190-200. [CrossRef]

14. Ordway, E.M.; Naylor, R.L.; Nkongho, R.N.; Lambin, E.F. Oil palm expansion and deforestation in Southwest Cameroon associated with proliferation of informal mills. Nat. Commun. 2019, 10, 114. [CrossRef] [PubMed]

15. Cochard, B.; Adon, B.; Kouame, R.K.; Durand-Gasselin, T.; Amblard, P. Advantages of improved commercial palm oil (Elaeis guineensis Jacq.) seeds. OCL Ol. Corps Gras Lipides 2001, 8, 654-658. [CrossRef]

16. Rafflegeau, S.; Michel-Dounias, I.; Tailliez, B.; Ndigui, B.; Papy, F. Unexpected N and K nutrition diagnosis in oil palm smallholdings using references of high-yielding industrial plantations. Agron. Sustain. Dev. 2010, 30, 777-787. [CrossRef]

17. Rafflegeau, S.; Nanda, D.; Genot, C. Artisanal mills and local production of palm oil by smallholders. In Achieving Sustainable Cultivation of Oil Palm; Volum 2: Diseases, Pests quality and sustainability; Burleigh Dodds Science Publishing: Cambridge, UK, 2018. [CrossRef]

18. Ghulam, K.A.P.; Elina, H.; Soh, K.L.; Meilina, O.A.; Kamalrudin, M.S.; Mohd, N.I.Z.B.; Shamala, S.; Zafarizal, A.A.H.; Zainab, I. Oil palm economic performance in Malaysia and R\&D progress in 2019. J. Oil Palm Res. 2020, 32, 159-190. [CrossRef]

19. Sarkar, M.S.K.; Begum, R.A.; Pereira, J.J. Impacts of climate change on oil palm production in Malaysia. Environ. Sci. Pollut. Res. 2020, 27, 9760-9770. [CrossRef] [PubMed]

20. Rafii, M.Y.; Rajanaidu, N.; Jalani, B.S.; Kushairi, A. Performance and heritability estimations on oil palm progenies tested in different environments. J. Oil Palm Res. 2002, 14, 15-24. 
21. Rafii, M.Y.; Isa, Z.A.; Kushairi, A.; Saleh, G.B.; Latif, M.A. Variation in yield components and vegetative traits in Malaysian oil palm (Elaeis guineensis jacq.) dura $\times$ pisifera hybrids under various planting densities. Ind. Crops Prod. 2013, 46, 147-157. [CrossRef]

22. Shabanimofrad, M.; Rafii, M.Y.; Wahab, P.M.; Biabani, A.R.; Latif, M.A. Phenotypic, genotypic and genetic divergence found in 48 newly collected Malaysian accessions of Jatropha curcas L. Ind. Crops Prod. 2013, 42, 543-551. [CrossRef]

23. Burton, G.W. Quantitative inheritance in grasses. In Proceedings of the 6th International Grassland Congress, State College, PA, USA, 17-23 August 1952; Volume 1, pp. 277-283.

24. Burton, G.W.; De Vane, E.H. Estimating heritability in tall fesscusce from replicated clone natural materials. Agron. J. 1952, 45, 171-181.

25. Singh, R.K.; Chaudhary, B.D. Biometrical Methods in Quantitative Genetic Analysis; Line x tester analysis; Kalyani publishers: New Delhi, India, 1985; Volume 3, pp. 215-223.

26. Johnson, H.W.; Robinson, H.F.; Comstock, R.E. Estimates of genetic and environmental variability in soybeans. Agron. J. 1955, 47, 314-318. [CrossRef]

27. Robinson, H.F.; Comstock, R.E.; Harvey, P.H. Genotypic and phenotypic correlation in corn and their implications in selection. Agron. J. 1949, 43, 282-287. [CrossRef]

28. Oladosu, Y.; Rafii, M.Y.; Abdullah, N.; Abdul Malek, M.; Rahim, H.A.; Hussin, G.; Latif, M.A.; Kareem, I. Genetic variability and selection criteria in rice mutant lines as revealed by quantitative traits. Sci. World J. 2014, 2014, 190531. [CrossRef] [PubMed]

29. Arolu, I.W.; Rafii, M.Y.; Marjuni, M.; Hanafi, M.M.; Sulaiman, Z.; Rahim, H.A.; Abidin, M.I.Z.; Amiruddin, M.D.; Din, A.K.; Nookiah, R. Breeding of high yielding and dwarf oil palm planting materials using Deli dura $\times$ Nigerian pisifera population. Euphytica 2017, 213, 154. [CrossRef]

30. Oettli, P.; Behera, S.K.; Yamagata, T. Climate based predictability of oil palm tree yield in Malaysia. Sci. Rep. 2018, 8, 2271. [CrossRef]

31. Ludwig, F.; Biemans, H.; Jacobs, C.; Supit, I.; Van Diepen, C.A.; Fawell, J.; Capri, E.; Steduto, P. Water Use of Oil Crops: Current Water Use and Future Outlooks; ILSI Europe Aisbl: Brussels, Belgium, 2011; Available online: https://library.wur.nl/WebQuery/ wurpubs/fulltext/193177 (accessed on 19 August 2020).

32. Myint, K.A.; Amiruddin, M.D.; Rafii, M.Y.; Samad, M.Y.A.; Ramlee, S.I.; Yaakub, Z.; Oladosu, Y. Genetic diversity and selection criteria of MPOB-Senegal oil palm (Elaeis guineensis Jacq.) germplasm by quantitative traits. Ind. Crops Prod. 2019, 139, 111558. [CrossRef]

33. Swaray, S.; Din Amiruddin, M.; Rafii, M.Y.; Jamian, S.; Ismail, M.F.; Jalloh, M.; Marjuni, M.; Mustakim Mohamad, M.; Yusuff, O. Influence of parental dura and pisifera genetic origins on oil palm fruit set ratio and yield components in their $\mathrm{D} \times \mathrm{P}$ progenies. Agronomy 2020, 10, 1793. [CrossRef]

34. Yusop, M.R.; Sukaimi, J.; Amiruddin, M.D.; Jalloh, M.; Swaray, S.; Yusuff, O.; Chukwu, S.C. Genetic improvement of oil palm through recurrent selection. In The Oil Palm Genome; Springer: Cham, Switzerland, 2020; pp. 35-46. [CrossRef]

35. Bhagasara, V.K.; Ranwah, B.R.; Meena, B.L.; Khan, R. Estimation of GCV, PCV, heritability and genetic gain for yield and its related components in sorghum [Sorghum bicolor (L.) Moench]. Int. J. Curr. Microbiol. Appl. Sci. 2017, 6, 1015-1024. [CrossRef]

36. Amiruddin, M.D.; Bakar, N.A.A.; Malike, F.A.; Mustaffa, S.; Abdullah, N.; Marjuni, M.; Mohamad, M.M.; Hassan, M.Y.; Kushairi, A.; Nookiah, R. Wild and Advanced Resources of Elaeis guineensis and Elaeis oleifera. In The Oil Palm Genome; Springer: Cham, Switzerland, 2020; pp. 9-23. [CrossRef] 